T4 and T3 occurred after the first dose of fenclofenac, but this would not explain the depressed TRH response seen on day 14. The repeated administration of TRH is unlikely to be responsible for this effect. ${ }^{4}$ It appears that fenclofenac, in addition to displacing thyroxine from its binding sites, has a thyroxine-like effect on the pituitary gland causing partial inhibition of the thyrotrophin response to TRH. We conclude that care must be taken to avoid a spurious diagnosis of hypothyroidism during fenclofenac treatment. The postulated effect of fenclofenac on the pituitary gland is being investigated.

We thank Dr Alan Cassells-Smith for biochemical tests, Dr Hans Ørskov for free thyroxine assays, and Professor K G M M Alberti for helpful advice.

${ }^{1}$ Weeke J, Ørskov H. Evaluation of thyroid function. In: Alberti KGMM, ed. Recent advances in clinical biochemistry. Edinburgh: Churchill Livingstone. 1978:116.

${ }^{2}$ Larsen PR, Atkinson AJ Jr, Wellman HN, et al. The effect of diphenylhydantoin on thyroxine metabolism in man. $\mathcal{f}$ Clin Invest 1970;49: 1266-79.

${ }^{3}$ Ratcliffe WA, Hazelton RA, Thomson JA. Effect of fenclofenac on thyroid function tests. Lancet $1980 ; \mathrm{i}: 432$.

${ }^{4}$ Haigler ED, Pittman JA, Hershman JM, Baugh CM. Direct evaluation of pituitary thyrotrophin reserve utilising synthetic thyrotrophin releasing hormone. 7 Clin Endocrinol Metab 1971;33:573-7.

${ }^{5}$ Sawin CT, Hershman JM. The TSH response to thyrotrophin releasing hormone in young adult men: Intra-individual variation and relation to basal serum TSH and thyroid hormones. $\mathcal{f}$ Clin Endocrinol Metab $1976 ; 42: 809-15$.

(Accepted 7 August 1980)

Newcastle University Hospitals, Newcastle upon Tyne NE4 6BE

R TAYLOR, MRCP, registrar in medicine

F CLARK, FRCP, consultant physician and senior lecturer in medicine

I D GRIFFITHS, MRCP, consultant rhematologist

Second University Clinic, Kommunehospitalet, Aarhus, Denmark J WEEKE, MD, senior lecturer

\section{Are reflectance meters necessary for home blood glucose monitoring?}

Tattersall recently discussed the role of reflectance meters in home blood glucose monitoring. ${ }^{1}$ A major factor limiting their wider use is their high cost. ${ }^{2}$ The Haemoglukotest $20-800$ reagent strip (Boehringer Mannheim) offers a considerable saving in capital outlay, since it can be read by eye alone. ${ }^{34}$ We discuss its possible role in home blood glucose monitoring.

\section{Patients, methods, and results}

The Haemoglukotest is specific for glucose. It has two separate test areas, whose indicators permit differentiation of eight pairs of colours corresponding to $1 \cdot 1,2 \cdot 2,4 \cdot 4,6 \cdot 7,10 \cdot 0,13 \cdot 3,22 \cdot 2$, and $44 \cdot 4 \mathrm{mmol}$ glucose $/ 1$ blood $(20,40$, $80,121 \cdot 8,181 \cdot 8,241 \cdot 8,403 \cdot 6$, and $807 \cdot 3 \mathrm{mg} / 100 \mathrm{ml}$ ).
Five diabetic patients, experienced in monitoring blood glucose concentrations at home using a Glucocheck reflectance meter (Medistron) and Dextrostix reagent strips (Ames), were asked to make an independent assessment of their blood glucose concentration at each test using the Haemoglukotest. Results of 242 pairs of tests were recorded by these five patients.

The table shows the number of tests performed in the clinic and at home corresponding to each Haemoglukotest value and the range of blood glucose concentrations (mmol 1 ; within $95 \%$ confidence limits) of these same samples tested by the autoanalyser and Glucocheck reflectance meter respectively.

\section{Comment}

A high overall correlation was obtained between the concentrations determined with the Haemoglukotest and the mean values measured by the autoanalyser and reflectance meter (mean value determined by autoanalyser $=1+0.88 \times$ Haemoglukotest value, $r=0.98$; mean value determined by reflectance meter $=0.2+1.08 \times$ Haemoglukotest value, $r=0.99$ ). The main disadvantage of the Haemoglukotest was its inability precisely to identify hypoglycaemia and hyperglycaemia at concentrations of 2.2 and $10.0 \mathrm{mmol} / 1$ (40 and $181.8 \mathrm{mg} / 100 \mathrm{ml}$ ) respectively.

The Haemoglukotest value of $2 \cdot 2 \mathrm{mmol} / 1(40 \mathrm{mg} / 100 \mathrm{ml})$ corresponded to a range in blood glucose concentrations of $1 \cdot 9-4 \cdot 1 \mathrm{mmol} / 1$ $(34.5-74.5 \mathrm{mg} / 100 \mathrm{ml} ; \mathrm{p}<0.05)$ as measured by the autoanalyser and $2 \cdot 1-4.3 \mathrm{mmol} / 1(38.2-78.2 \mathrm{mg} / 100 \mathrm{ml} ; \mathrm{p}<0.05)$ as measured by the reflectance meter. Similarly, the Haemoglukotest value of $10.0 \mathrm{mmol} / \mathrm{l}$ $(181.8 \mathrm{mg} / 100 \mathrm{ml})$ corresponded to a range of $7-14.2 \mathrm{mmol} / 1(127 \cdot 3-$ $258.2 \mathrm{mg} / 100 \mathrm{ml} ; \mathrm{p}<0.05)$ and $7 \cdot 3-13.7 \mathrm{mmol} / 1(132 \cdot 8-249 \cdot 1 \mathrm{mg} / 100$ $\mathrm{ml} ; \mathrm{p}<0.05)$ as measured by the autoanalyser and reflectance meter respectively. This need not be a major drawback if these values are interpreted in a clinical context. The values of 13.3 and $22.2 \mathrm{mmol} / \mathrm{l}$ $(241.8$ and $403.6 \mathrm{mg} / 100 \mathrm{ml})$ constantly represented blood glucose concentrations in the hyperglycaemic range while that of $1.1 \mathrm{mmol} / 1$ $(20 \mathrm{mg} / 100 \mathrm{ml})$ represented four samples all of which had concentrations under $2 \cdot 2 \mathrm{mmol} / 1(40 \mathrm{mg} / 100 \mathrm{ml})$. On the other hand, the values of 4.4 and $6.7 \mathrm{mmol} / 1$ ( 80 and $121.8 \mathrm{mg} / 100 \mathrm{ml}$ ) almost always corresponded to blood glucose concentrations (as measured by the autoanalyser and reflectance meter) within the normal range.

The main advantages of the Haemoglukotest were simplicity and convenience. Furthermore, 25 strips cost $£ 2.90$ compared with a cost of $£ 91.00$ for a Glucocheck meter and $£ 2.65$ for 25 Dextrostix strips. We conclude that the Haemoglukotest $20-800$ offers a simple, cheap alternative method of monitoring blood glucose concentrations at home.

1 Tattersall RB. Home blood glucose monitoring. Diabetologia 1979;16: 71-4.

2 Webb DJ, Lovesay JM, Ellis E, Knight AH. Blood glucose monitors: a laboratory and patient assessment. $B r$ Med $\mathcal{F} 1980 ; 280$ :362-4.

${ }^{3}$ Lawson PM, Kesson CM, Ireland JT. Performance of blood glucose strips. Lancet 1979 ;ii:742.

${ }^{4}$ Walford S, Clarke P, Paisey R, Hartog M, Allison SP. Home blood glucose measurements without a reflectance meter. Lancet 1980;i :653-4.

(Accepted 21 fuly 1980)

Department of Paediatrics, Royal Gwent Hospital, Newport, Gwent

$S$ D FERGUSON, MB, MRCP, registrar in paediatrics

R PROSSER, MB, FRCP, consultant paediatrician
Random venous blood samples were taken from 32 diabetic children, 24 non-diabetic children, and three small-for-dates babies who were transiently hypoglycaemic at birth. Part of the sample was tested by the patient, his parent, or both independently using the Haemoglukotest. If the test colour did not exactly correspond to any of the eight values, the tester was asked to choose the nearest match. A total of 102 assessments were made on 59 blood samples, which were then tested in the laboratory autoanalyser by a modified glucose oxidase method.

\section{Correction}

\section{Jet injection of insulin}

A printing error occurred in this paper by Dr $\mathrm{R}$ Worth and others (13 September, $p$ 713). The age range mentioned in the first sentence of Patients, methods, and results should have read "17-78." 